\begin{tabular}{|l|l|l||}
\hline \multicolumn{2}{|c|}{ PublisherInfo } \\
\hline \hline PublisherName & $:$ & BioMed Central \\
\hline \hline PublisherLocation & $:$ & London \\
\hline \hline PublisherImprintName & $:$ & BioMed Central \\
\hline \hline
\end{tabular}

\title{
Antagonist of chemokine receptors CCR1 and CCR3
}

\begin{tabular}{|l|l|l||}
\hline \multicolumn{2}{|c||}{ ArticleInfo } \\
\hline \hline ArticleID & $:$ & 1633 \\
\hline \hline ArticleDOI & $:$ & $10.1186 /$ rr-2001-68565 \\
\hline \hline ArticleCitationID & $:$ & 68565 \\
\hline \hline ArticleSequenceNumber & $:$ & 44 \\
\hline \hline ArticleCategory & $:$ & Paper Report \\
\hline \hline ArticleFirstPage & $:$ & 1 \\
\hline \hline ArticleLastPage & $:$ & 4 \\
\hline \hline & & RegistrationDate $: 2001-9-19$ \\
ArticleHistory & $:$ & Received \\
& $:$ 2000-11-13 \\
\hline \hline ArticleCopyright & $:$ & Biomed Central Ltd2001 \\
\hline \hline ArticleGrants & $:$ & \\
\hline \hline ArticleContext & $:$ & 129312211 \\
\hline \hline
\end{tabular}


Alaina Ammit, ${ }^{\text {Affl }}$

Corresponding Affiliation: Aff1

Aff1 Pulmonary and Critical Care Division, Department of Medicine, University of Pennsylvania, USA

\section{Keywords}

CCR1, CCR5, eosinophils, eotaxin, MIP-1a, monocytes

\section{Context}

Trafficking and activation of leukocytes plays a significant role in the initiation and perpetuation of airway inflammation and bronchial hyperreactivity in asthma. The chemokine family of proteins is central to the regulation of selective leukocyte recruitment. Because chemokines activate $G$ proteincoupled seven-transmembrane chemokine receptors (CCR) on the cell surface of leukocytes, there is considerable interest in the development of receptor antagonists. In this study, the authors examine the ability of a compound known as UCB35625 (the trans-isomer J113863 published by Banyu Pharmaceutical Co, patent WO98/04554), to act as a CCR1 and CCR3 receptor antagonist.

\section{Significant findings}

UCB35625 inhibited eosinophil shape change in response to eotaxin and MCP-4, two chemokines that act exclusively via CCR3. UCB35625 was more efficacious at impeding the actions of MIP-1a on CCR1-mediated eosinophil shape change. UCB35625 also inhibited MIP-1a induced shape change of human monocytes. Importantly, MCP-1, which acts at the receptor CCR2 on monocytes, was unaffected by UCB35625, showing that the compound exhibits selectivity. Clones of the murine pre-B cell line 4DE4 stably transfected with either CCR1 or CCR3 were used to demonstrate a chemotactic response to MIP-1a and eotaxin, respectively. This was inhibited by UCB35625, with CCR1-mediated chemotaxis being approximately 10 -fold more sensitive to the compound. To further demonstrate the selectivity of UCB35625, chemotaxis of the naive 4DE4 cells to SDF-1 (the ligand for constitutively expressed CXCR4) was shown to be unaffected by similar doses of the compound. UCB35625 was able to block chemokine-induced receptor internalization and again, the compound was more potent at CCR1 than CCR3. However, competitive ligand binding assays on the same transfectants revealed that considerably 
larger concentrations of UCB35625 were needed for effective ligand displacement than were needed for the inhibition of receptor function. Therefore, the authors conclude that UCB35625 is a potent and selective inhibitor of CCR1 and CCR3, and it appears that the compound may interact with a region present in both receptors that inhibits the conformational change necessary to initiate intracellular signalling.

\section{Comments}

Although this study was unable to elucidate the precise mechanism of action(s) of the compound UCB35625, to date, only a small number of publications have reported the development of low molecular weight chemokine receptor antagonists, and this is the first to identify a dual CCR1/CCR3 receptor antagonist. However, the discovery of novel chemokine receptor antagonists is an area under intense investigation (see Additional information). Because UCB35625 potently inhibits CCR1 and CCR3, it may act as a lead compound for the design of future therapeutics, and may be of use in the treatment of allergic inflammatory diseases such as asthma.

\section{Methods}

Transfection, chemotaxis, calcium fluorimetry, FACS, radioligand binding assay

\section{Additional information}

White JR, Lee JM, Dede K, Imburgia CS, Jurewicz AJ, Chan G, Fornwold JA, Dhanak D, Christmann LT, Darcy MG, Widdowson KL, Foley JJ, Schmidt DB, Sarau HM: Identification of potent, selective non-peptide CCR3 antagonist that inhibits eotaxin-, eotaxin-2 and MCP-4 induced eosinophil migration.

J Biol Chem 2000 [epub ahead of print]. 


\section{References}

1. Sabroe I, Peck MJ, Van Keulen BJ, Jorritsma A, Simmons G, Clapham PR, Williams TJ, Pease JE: A small molecule antagonist of chemokine receptors CCR1 and CCR3: potent inhibition of eosinophil function and CCR3-mediated HIV-1. J Biol Chem . 2000, 275: 25985-25992.

This PDF file was created after publication. 